\title{
Harbour porpoises in the Aegean Sea, Eastern Mediterranean: the species' presence is confirmed
}

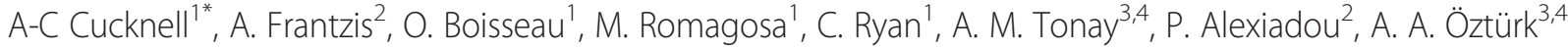 \\ and A. Moscrop'
}

\begin{abstract}
Results are presented from the first systematic visual and acoustic line-transect survey for harbour porpoises in the Thracian Sea, northern Aegean Sea. During the vessel survey, undertaken in summer 2013, porpoises were observed on nine occasions and detected acoustically 16 times, with a total of 21 distinct encounters recorded. Harbour porpoises were encountered in three discrete blocks: north of the Island of Thasos, Greece; south and west of the city of Alexandroupolis, Greece; and in Saros Bay, Turkey. Saros Bay exhibited the highest relative acoustic encounter rate of harbour porpoises, and porpoises were observed visually there on two occasions 14 days apart, in small groups, one of which included a mother-calf pair. A comprehensive review of stranding records is also presented. The three areas identified as harbour porpoise habitat in this study coincide with the highest number of recorded stranded animals. This paper is the first to report free-swimming harbour porpoises in the Aegean Sea since 1993, and the first time ever in Turkish Aegean waters. Now that the presence of harbour porpoises has been documented, international cooperation towards long term monitoring and management measures are urgently required in order to conserve this vulnerable population.
\end{abstract}

Keywords: Phocoena phocoena, Harbour porpoise, Acoustic survey, Aegean Sea, Mediterranean Sea, Endangered, Zoogeography

\section{Background}

Harbour porpoises (Phocoena phocoena, Linnaeus 1758) are distributed widely throughout continental shelf waters of the Northern Hemisphere and are present in the eastern North Atlantic Ocean and Black Sea (Gaskin 1984; Read 1999; Hammond et al. 2013). The historical presence of harbour porpoises in the Mediterranean Sea has been debated in the past (Frantzis et al. 2001, 2003; Notarbartolo di Sciara 2002; Rosel et al. 2003; ViaudMartínez et al. 2007; Fontaine et al. 2012). Prior to this study there were 21 published records of harbour porpoises documented in the Mediterranean Sea dating back to 1981 (Frantzis et al. 2001; Bellido et al. 2006; Frantzis 2009; Tonay et al. 2009; Notarbartolo di Sciara \& Birkun 2010; Tonay \& Dede 2013) with all but two

\footnotetext{
* Correspondence: acucknell@mcr-team.org

${ }^{1}$ Marine Conservation Research International, 94 High Street, Kelvedon, Essex CO5 9AA, UK

Full list of author information is available at the end of the article
}

reported from the Aegean Sea; the remaining two records were from the Strait of Gibraltar and the waters of Tunisia. These previous records are mostly intermittent strandings, although in 1993 there was a confirmed report of free-swimming porpoises followed by three strandings in the north of the Thracian Sea, including a live-stranded animal (Frantzis et al. 2001).

It is likely that the increase in harbour porpoise records in the Aegean Sea during the last two decades is due to an increased effort in reporting of stranded animals from coordinated stranding networks and improved public awareness of marine mammals (Rosel et al. 2003), although a genuine increase in the number of individuals in the region cannot be excluded. In Greece, the portpolice have been responsible for collating stranding records from the public since 1991. Since 2000 it has been mandatory to report stranded cetaceans; this has increased the number of cetacean strandings reported from 50 to 75 each year to around 100. Since 2010, the Pelagos Cetacean 
Research Institute has systematically recorded Greek cetacean strandings through a national stranding network involving port-police authorities and volunteers, with an average of 125 events reported per year since this date. Although Turkey does not have a systematic stranding scheme, Istanbul University/Turkish Marine Research Foundation collates stranding records opportunistically. With the development of the internet and smart phones over the last 10 years, there has been an increase in the public awareness of the importance of reporting strandings in Turkish waters.

Results from a molecular genetic study indicate that the Black Sea population of harbour porpoises is distinct from the Atlantic population, having been isolated by the Mediterranean Sea over 5000 years ago (Fontaine et al. 2010). Due to the very limited geographic area within the Mediterranean Sea where sightings and strandings have been recorded in the past (Aegean Sea and close to the Strait of Gibraltar), the presence of a continuous population of harbour porpoises linking the Atlantic and Black Sea populations is considered very unlikely (Frantzis et al. 2001). From genetic analyses of stranded specimens, harbour porpoises in the Aegean Sea have been found to share common haplotypes with harbour porpoises in the Black Sea as well as in the Turkish Straits System (Viaud-Martínez et al. 2007; Tonay et al. 2014). It is therefore thought that these Aegean porpoises are migrants from the Black Sea population (Rosel et al. 2003; Viaud-Martínez et al. 2007; Tonay et al. 2012, 2014). The possibility still exists however, that Black Sea and Aegean Sea harbour porpoises could form a single random-mating (panmictic) population (Fontaine et al. 2012), or that harbour porpoises sighted in the northern Aegean Sea are from a small isolated Mediterranean population (Rosel et al. 2003; Notarbartolo di Sciara \& Birkun 2010). Indeed, five harbour porpoises found stranded in the Marmara Sea, between the Black Sea and the Aegean Sea, exhibit a unique haplotype, suggesting that these individuals may comprise a distinct and isolated population (ViaudMartínez et al. 2007; Tonay et al. 2012, 2014). However, with sample sizes as small as those reported from the region, caution must be exhibited in interpreting the genetic results.

The Black Sea harbour porpoise ( $P$. phocoena relicta, Abel 1905) subspecies has recently been listed on the IUCN Red List as Endangered (Birkun \& Frantzis 2008), both genetically and morphologically distinct from the eastern North Atlantic population (Rosel et al. 1995, Rosel et al. 2003; Fontaine et al. 2007, 2010; ViaudMartínez et al. 2007; Galatius \& Gol'din 2011; Tonay et al. 2014). The Agreement on the Conservation of Cetaceans in the Black Sea, Mediterranean Sea, and Contiguous Atlantic Area (ACCOBAMS) noted four "priority" species in the Mediterranean and Black Seas (Notarbartolo di Sciara 2002) which were at greatest risk of declining or disappearing. The harbour porpoise was among them. Over the last 50 years the Black Sea harbour porpoise population is thought to have been reduced to just $10 \%$ of its former size (Fontaine et al. 2010, study based on genetics). This has been attributed to a commercial dolphin fishery which continued until 1983, in addition to high mortality from bycatch in bottom set gillnets, habitat degradation (Birkun \& Frantzis 2008) and pollution (Notarbartolo di Sciara 2002; Ozturk 2013). This sub-species clearly requires urgent protection from anthropogenic impacts throughout its range, including the Aegean Sea.

In order to document the presence and distribution of harbour porpoises in the Thracian Sea, a simultaneous visual and acoustic survey was conducted in the northern Aegean Sea. The results from this first systematic survey for harbour porpoises in the Greek and Turkish waters of the Thracian Sea are presented here, together with an update on stranding records.

\section{Materials and methods}

A simultaneous visual and acoustic survey for harbour porpoises was conducted in the Thracian Sea, northern Aegean, between 7 and 26 July 2013, planned to coincide with an aerial survey of cetaceans in the western Black Sea (Birkun et al. 2014) (Table 1).

\section{Study area}

The Thracian Sea is located in the northern Aegean Sea (Fig. 1) and extends from the Chalkidi Peninsula in Greece in the west to the Turkish Gelibolu (Gallipoli) Peninsula in the east, and the Greek and Turkish mainland in the north to the island of Lemnos in the south (see Fig. 1). The Thracian Sea is connected to the Black Sea through the Turkish Straits System; currents carry the less saline waters of the Black Sea near the surface through the straits, with the more saline Thracian Sea water flowing in the opposite direction in the deeper

Table 1 The designed survey blocks and line lengths for the study site in the north Aegean Sea

\begin{tabular}{lll}
\hline Block/survey & Area $\left(\mathrm{km}^{2}\right)$ & Designed line length $(\mathrm{km})$ \\
\hline Low resolution survey area & 16,409 & 2,176 \\
Block 1 & 1,693 & 332 \\
Block 2 & 595 & 175 \\
Block 3 & 712 & 141 \\
Block 4 & 500 & 116 \\
Block 5 & 1,151 & $239+240$ \\
Block 6 & 890 & 72 \\
Block 7 & 695 & 139
\end{tabular}

ahad reciprocal tracks 


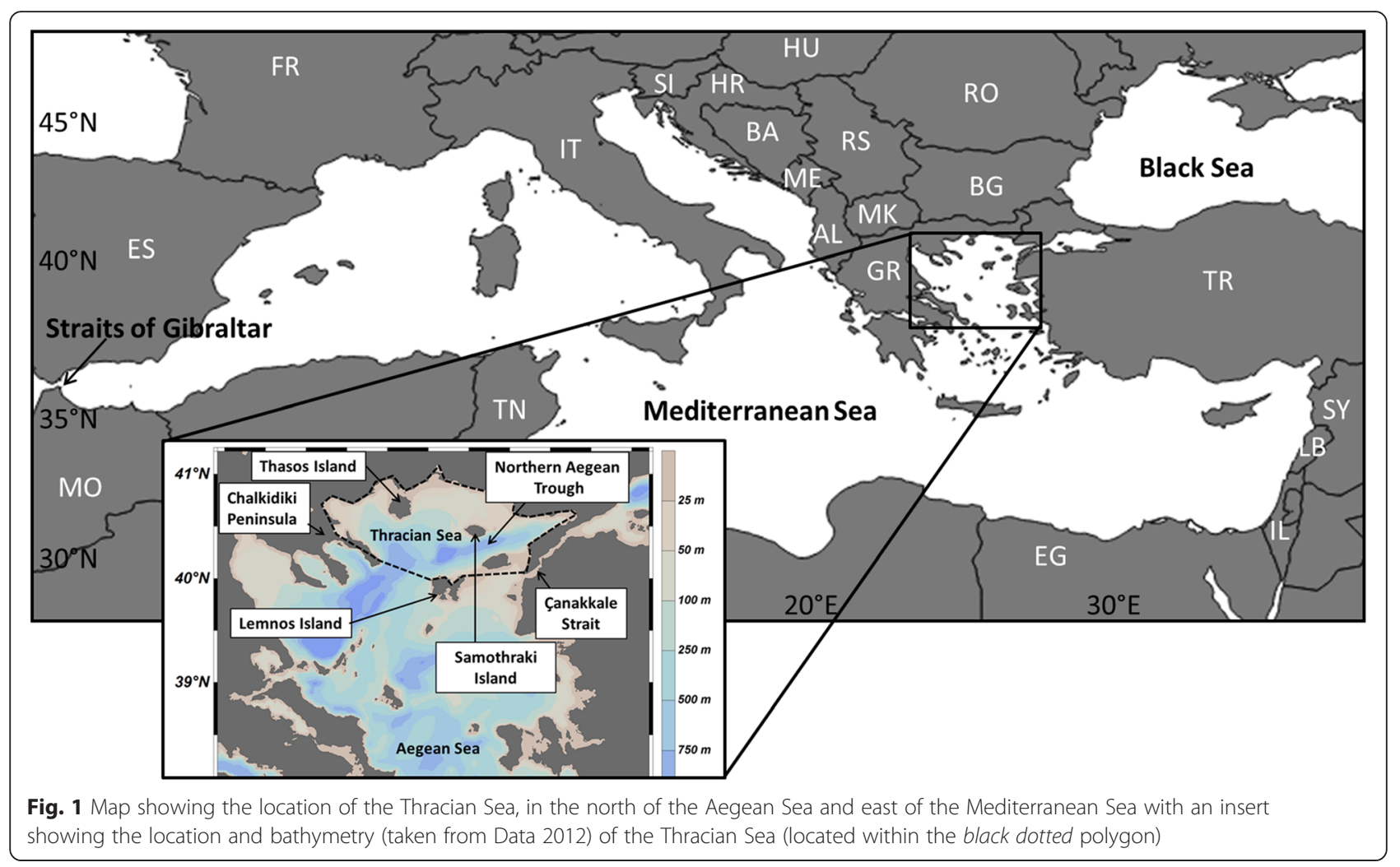

layer. The prevailing currents in the Thracian Sea move in a clockwise direction, from the Black Sea, and around Thasos Island (Lykousis et al. 2002). The Thracian Basin contains the islands of Samothraki and Thasos, an extended plateau, and the North Aegean trough, a $1600 \mathrm{~m}$ deep basin; excluding the deep basin, the majority of the Thracian Sea is relatively shallow, at less than hundred metres deep (see Fig. 1).

\section{Visual and acoustic harbour porpoise survey}

A double platform visual survey was conducted following Hammond et al. (2013) which, if sufficient sightings are achieved, allows for abundance estimation, corrected for perception bias and availability bias. However, as fewer than 60 groups were encountered, abundance estimation was subsequently deemed inappropriate using this method (Buckland et al. 2001). The survey tracks were designed using DISTANCE 6.0 (Thomas et al. 2010) and included both broad scale, low resolution survey tracks over the entire area and a number of higher resolution tracks close to the Greek and Turkish coastline. The low resolution tracks were designed to provide information about harbour porpoise presence across the North Aegean Sea and inform the subsequent high resolution tracks; these were designed to survey in more detail the typical harbour porpoise coastal habitat. The tracks were adjusted-angle zigzags designed randomly to ensure equal coverage probability of the survey blocks.
The design axes were selected based on local prevailing winds to increase the potential for sailing. The research cruise was conducted from $\mathrm{R} / \mathrm{V}$ Song of the Whale (SOTW), a $21 \mathrm{~m}$ auxiliary-powered cutter-rigged sailing research vessel.

During daylight hours and in sea state conditions of three and under, four observers divided equally between two independent platforms scanned for porpoises. Two naked-eye 'primary' observers logged sightings within a range of $500 \mathrm{~m}$ from a platform in front of the mast giving an approximate eye-height of $4 \mathrm{~m}$. Two 'trackers', situated either side of the vessel on an A-frame with an approximate eye-height of $5.5 \mathrm{~m}$ above sea-level, scanned the trackline and in front of the vessel using $7 \times 50$ binoculars. Once the 'trackers' had seen a group of porpoises, one of the 'trackers' would follow the group as it passed the vessel in order to determine if any avoidance behaviour was observed. Whenever possible, photographs were taken by an off-effort individual to confirm species identification. However, if potential sightings of porpoise groups were too far away to confirm species identity, the vessel briefly went off-effort to break track and acquire species identification photographs, before resuming the survey where it had been interrupted. In sea state conditions four and above, only two observers using binoculars on the A frame were deployed. All details of sightings and acoustic detections were recorded by the data logger using Logger software (Gillespie et al. 2010). Additionally, the 
data logger recorded the survey effort and environmental data as well as the certainty of species identification. Only those sightings identified as harbour porpoise with 'definite' certainty were included in this analysis.

The acoustic survey was conducted simultaneously with the visual survey although an independence was maintained between the two (i.e. observers were not notified of acoustic detections). The acoustic survey was conducted in all sea states including the hours of darkness. Two towed arrays, each containing a pair of broadband elements with a bandwidth of 2 to $200 \mathrm{kHz}$ spaced $25 \mathrm{~cm}$ apart, were towed $200 \mathrm{~m}$ behind the vessel $3 \mathrm{~m}$ apart, to allow for correction of left/right ambiguity of detections. Signals were passed through Seiche Measurements buffer boxes to internal National Instruments 6251 sound cards. The buffer boxes provided an approximately flat frequency response for the bandwidths of interest for harbour porpoises $( \pm 1 \mathrm{~dB}$ from 115 to $160 \mathrm{kHz})$. Audio streams from each array were sampled at $500 \mathrm{kHz}$ and recorded continuously as separate 16-bit stereo wav files using Pamguard (Gillespie et al. 2009). Post survey analysis was conducted using a Pamguard click detection module configured for harbour porpoises and an analyst removed any false detections and selected detection trains. Clicks were classified as 'definite' harbour porpoise clicks if they met the following criteria: the click had a peak frequency between 100 and $160 \mathrm{kHz}$, the energy of the click was at least $8 \mathrm{~dB}$ above the background noise levels and less than $2 \mathrm{~ms}$ in duration, with a relatively flat structure (i.e. not frequency modulated) as revealed in a Wigner plot. All clicks were independently verified by a second analyst and only click trains with at least four clicks and which were listed as 'definite' were included. Click trains were considered to be a unique detection (i.e. not a detection of an animal previously sighted or a repeat detection of a previous group) if there was no corresponding sighting or click train within $6 \mathrm{~min}$. This is a conservative figure which was calculated using the average speed of SOTW (6 knots), the maximum detection distance for harbour porpoises (approximately $400 \mathrm{~m}$; Villadsgaard et al. 2006) and the average swimming speed of harbour porpoises $(0.9 \mathrm{~m} \mathrm{sec}$ ${ }^{-1}$; Otani et al. 2006).

Water depths and distances from the coast for each sighting and detection were estimated using GEBCO 2008 bathymetry maps (British Oceanographic Data Centre; 1 min resolution). Sea-surface temperatures were automatically collected every minute from a thermometer mounted on the hull of the vessel.

\section{Data analysis}

The standard error (SE) for the detection rate $n$ / $100 \mathrm{~km}$, was calculated using transects as sampling units (Buckland et al. 2001, pp78-80). The variance in the number of detections for each block (Fig. 2) was calculated as follows:

$$
v \hat{a} r(n)=L \sum_{i=1}^{k} l_{i}\left(\frac{n_{i}}{l_{i}}-\frac{n}{L}\right)^{2} /(k-1)
$$

where $i$ is the transect number from 1 to $k, l_{i}$ is the length of transect $i$ and $L$ is the sum of all transect lengths. The variance of the detection rate was then calculated by dividing vâr $(n)$ by $L^{2}$ and the standard error (SE) in each block was calculated by taking the square root of the variance of the detection rate.

\section{Strandings data}

Strandings data, including novel data collated by the Pelagos Cetacean Research Institute are presented and combined with the previous 19 published stranding records in Greek and Turkish waters of the Aegean Sea and Çanakkale Strait.

\section{Comparison of acoustic encounter rates}

The acoustic encounter rates from this survey were adapted so as to be comparable with previous harbour porpoise surveys conducted from R/V Song of the Whale in other small, isolated populations. Only acoustic detections with seven clicks or more were included so to allow comparison with other studies methodologies (elsewhere in the results, click trains of four or more clicks have been used).

\section{Results}

\section{Acoustic and visual harbour porpoise survey}

The harbour porpoise survey of the northern Aegean Sea included $2845 \mathrm{~km}$ of transect which utilised at least acoustic effort, $529 \mathrm{~km}$ with both visual and acoustic effort and $845 \mathrm{~km}$ with both double platform visual effort and acoustic effort (Fig. 2). The mode sea state during this survey was two; however during many parts of the survey the sea state exceeded three and therefore only single observer visual effort was conducted during these times (see Table 2 for more information).

There were 21 distinct encounters with harbour porpoises during the survey; 12 were detected solely with acoustic techniques, five were sighted only, and four were sighted with simultaneous acoustic detection. Nine definite sightings of harbour porpoises were made on two separate days, all within Saros Bay in Turkish Aegean waters (Table 2 and Fig. 3). Six groups of porpoises were first spotted from the 'tracker' platform (with three of these subsequently re-sighted by the 'primary' observers) and three from the 'primary' platform. On 12 July 2013, four sightings of porpoises were made; one of a group of four animals, two sightings of two animals and a further sighting of a single individual. Several re-sightings were 


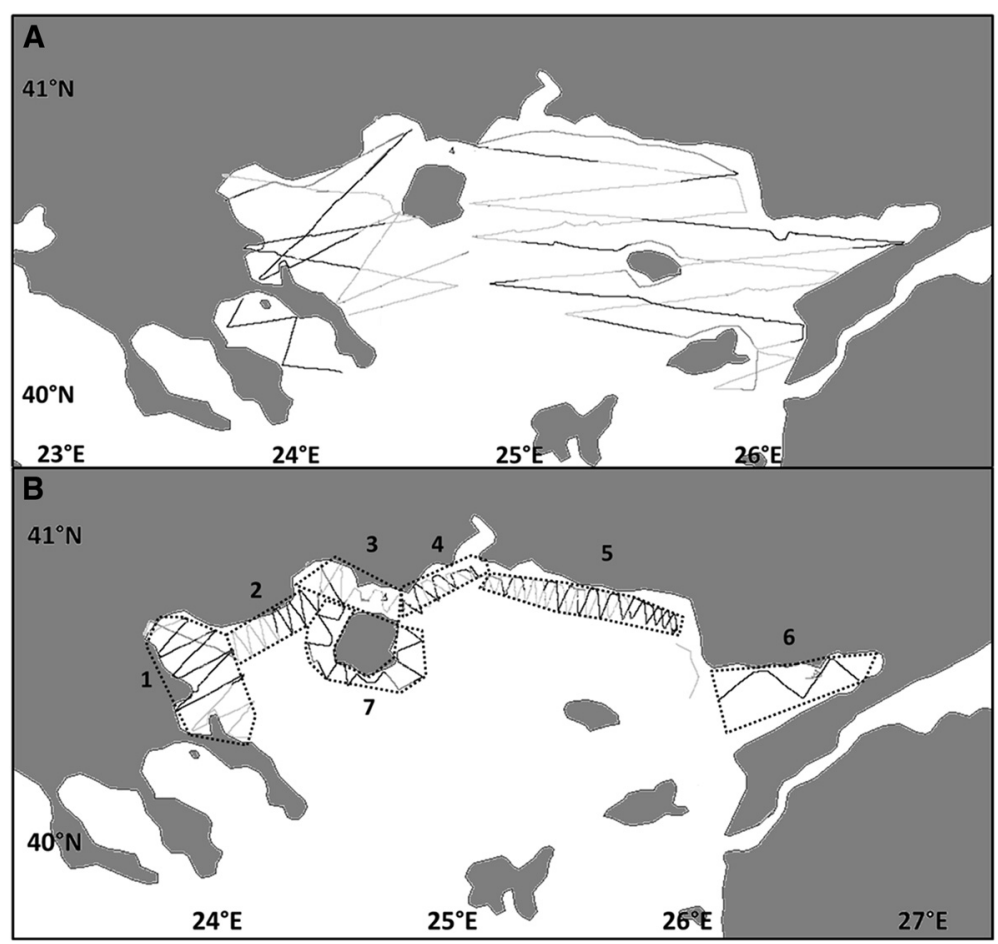

Fig. 2 Survey tracks conducted by SOTW in the northern Aegean Sea (black lines represent survey with visual and acoustic effort and grey lines represent the survey with acoustic effort only) a low resolution transects, $\mathbf{b}$ higher resolution coastal blocks (marked 1-7, black dotted line) and coastal transects

made both from the primary platform and whilst tracking the animals. After completing the remaining low resolution transects, the survey vessel returned to Saros Bay 2 weeks later, as part of the higher resolution coastal survey. On 26 July, harbour porpoises were encountered on five separate occasions, including three pairs of animals and two single individuals. One of the pairs sighted included a calf swimming in echelon position with another animal, presumably the mother. Photographs were taken during all encounters in order to confirm species identification (Fig. 4). During both days when porpoises were seen in Saros Bay, there were good sighting conditions (the sea state was between 0 and 3 ).

Acoustic detections of porpoises $(n=16$, of which 14 were made 'on track' i.e. following pre-determined tracklines at the prescribed survey speed) were made in Greek and Turkish waters, four of which were accompanied by visual encounters. Eight unique acoustic detections occurred to the north of the Greek island of Thasos, three west of the Greek city of Alexandroupolis, and five in Saros Bay, off Turkey (Fig. 3). Each of the reported acoustic detections was separated by a minimum of $12 \mathrm{~min}$ and was therefore deemed to be an independent encounter (see Methods section for definition).

Relative 'on track' acoustic encounter rates $(n / 100 \mathrm{~km}$ surveyed) were calculated for the high resolution coastal survey (overall and per block) and for the northern
Aegean (Thracian Sea) survey as a whole, including both the high and low resolution survey blocks (Table 2). The high resolution coastal transects of the Saros Bay survey block (block 6) revealed the highest acoustic encounter rate (Table 2 and Fig. 2).

During July, surface water temperatures in Saros Bay increased from 19 to $25^{\circ} \mathrm{C}$, over the 2 week period when the harbour porpoises were sighted. The 21 encounters occurred in water of varying depths (mean depth $=43 \mathrm{~m}$, $\mathrm{SD}=27 \mathrm{~m}$ ) but all sightings and detections occurred in waters shallower than $150 \mathrm{~m}$ (see Fig. 1 for bathymetry). All of the encounters occurred at distances $<6 \mathrm{~nm}$ from the coast (mean distance $=1.8 \mathrm{~nm}, \mathrm{SD}=0.12$ ).

Four other cetacean species were sighted while surveying the Thracian Sea, the common bottlenose (Tursiops truncatus) $(n=45)$, short-beaked common (Delphinus delphis) $(n=16)$ and striped (Stenella coeruleoalba) dolphin $(n=20)$ and Risso's dolphins (Grampus griseus) $(n=1)$ (for more information see Ryan et al. 2014).

\section{New stranding data}

Previously, 19 strandings of harbour porpoises have been reported between 1997 and 2013 in Greek and Turkish waters of the Aegean Sea and Çanakkale Strait (Güçlüsoy 2007; Frantzis 2009; Tonay \& Dede 2013). There has also been ten unpublished strandings of harbour porpoises between 2007 and 2013, including 
Table 2 Survey effort, detection rate, number of detections, time and date of detections, number of sightings, sea state histogram and percentage of effort surveyed in the hours of darkness for the 2013 harbour porpoise Aegean Sea survey. Acoustic effort was conducted throughout the entire survey regardless of sea state or light level

\begin{tabular}{|c|c|c|c|c|c|c|c|}
\hline Survey/block & $\begin{array}{l}\text { Acoustic effort } \\
\text { (visual effort) km }\end{array}$ & $\begin{array}{l}\text { On-track acoustic detections } \\
n / 100 \mathrm{~km}(\mathrm{SE} \text { of } n / 100 \mathrm{~km})\end{array}$ & $\begin{array}{l}\text { No of } \\
\text { detections }\end{array}$ & $\begin{array}{l}\text { Date/time of acoustic } \\
\text { detection (UTC) }\end{array}$ & $\begin{array}{l}\text { No of sightings } \\
\text { (individuals) }\end{array}$ & $\begin{array}{l}\text { Sea state histogram } \\
\text { for daylight hours }\end{array}$ & $\begin{array}{l}\text { \% of the transect lines } \\
\text { surveyed at night } \\
\text { (acoustic only) }\end{array}$ \\
\hline \multirow[t]{4}{*}{ Low resolution survey } & \multirow[t]{4}{*}{$1690(717)$} & \multirow[t]{4}{*}{$0.24(0.17)$} & \multirow[t]{4}{*}{4} & 08/07/2013 06:53:56 & \multirow[t]{4}{*}{$4(9)$} & & \multirow[t]{4}{*}{48} \\
\hline & & & & 08/07/2013 13:18:56 & & & \\
\hline & & & & 08/07/2013 13:32:39 & & & \\
\hline & & & & 15/07/2013 12:13:32 & & & \\
\hline High resolution survey & 1155 (658) & $0.87(0.30)$ & 10 & $\mathrm{n} / \mathrm{a}$ & $5(8)$ & & 43 \\
\hline
\end{tabular}

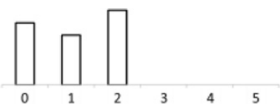

21/07/2013 23:41:50
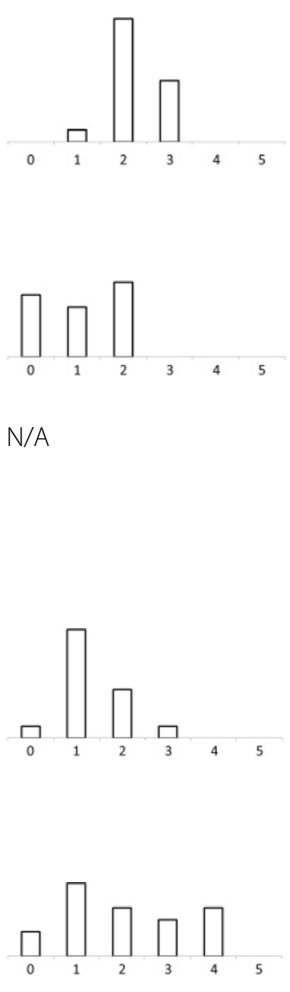
Table 2 Survey effort, detection rate, number of detections, time and date of detections, number of sightings, sea state histogram and percentage of effort surveyed in the hours of darkness for the 2013 harbour porpoise Aegean Sea survey. Acoustic effort was conducted throughout the entire survey regardless of sea state or light level (Continued)

Area 6

$54(65)$

$5.61(4.29)$

26/07/2013 12:15:48

26/07/2013 14:09:14

Area 7

$136(115)$

$0(0)$

$n / a$

Combined high and low

resolution survey results

$2845(1375)$

$0.49(0.18)$

14
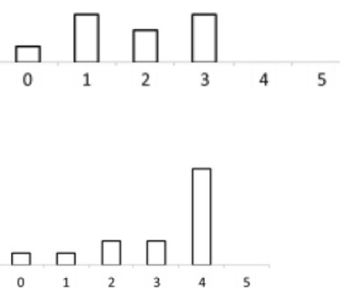

46

${ }^{\mathrm{a}} 2$ off track detections also occurred on 26/07/2013 


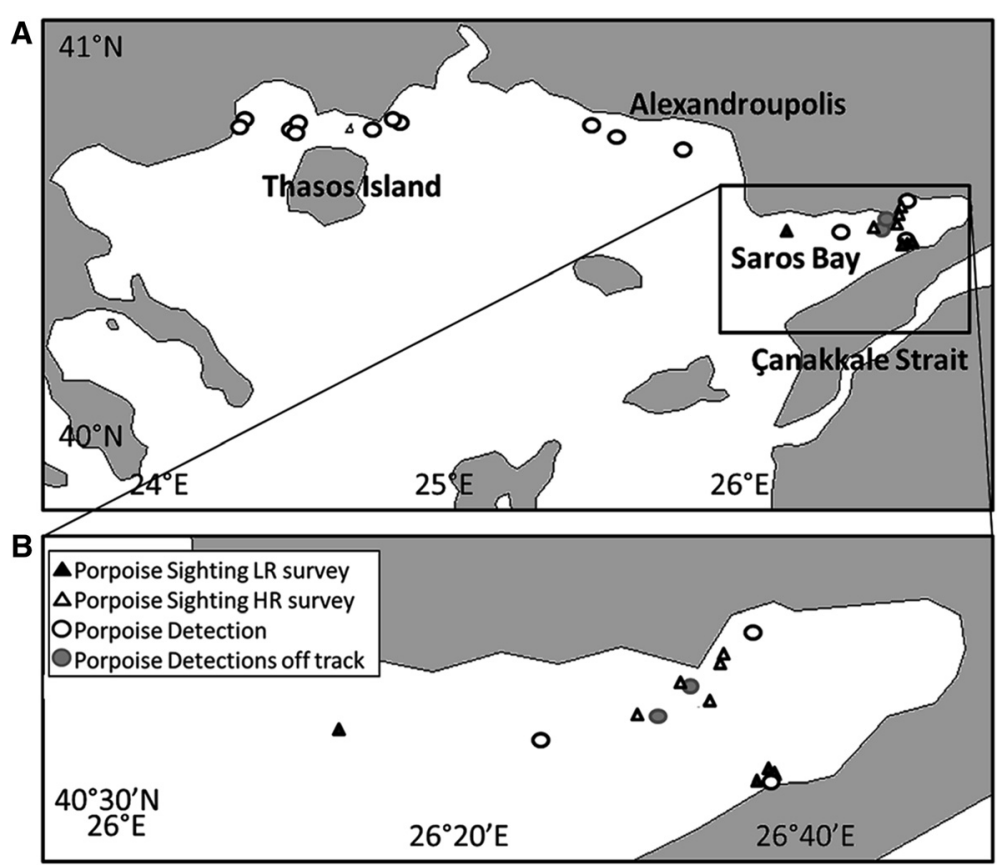

Fig. 3 a Map depicting the locations of harbour porpoise detections $(n=16)$ and sightings $(n=9)$ across the Greek and Turkish waters of the Thracian Sea. $\mathbf{b}$ an enlarged map of Saros Bay, Turkey depicting the porpoise sightings $(n=4)$ on the 12/07/2013 during the low resolution survey and sightings $(n=5)$ and detections ( $n=3$ "on track"; $n=2$ "off track") during the high resolution coastal tracks on 26/07/2013

four in 2013 alone, in Greek coastal waters (Fig. 5) (Pelagos Cetacean Research Institute, unpublished data). The majority of the strandings were found along the northern Aegean Sea coastline, north-west of Thasos Island and close to Alexandroupolis. However, since 2006 there has been an increase in the number of strandings of harbour porpoises reported further to the south of the Aegean Sea with six strandings recorded in latitudes south of $39^{\circ} \mathrm{N}$ (Tonay \& Dede 2013 and Pelagos Cetacean Research Institute, unpublished data). At least three of the southern stranded porpoises presented heavy infestations of an ectoparasite (Pennella sp.) (Danyer et al. 2014;

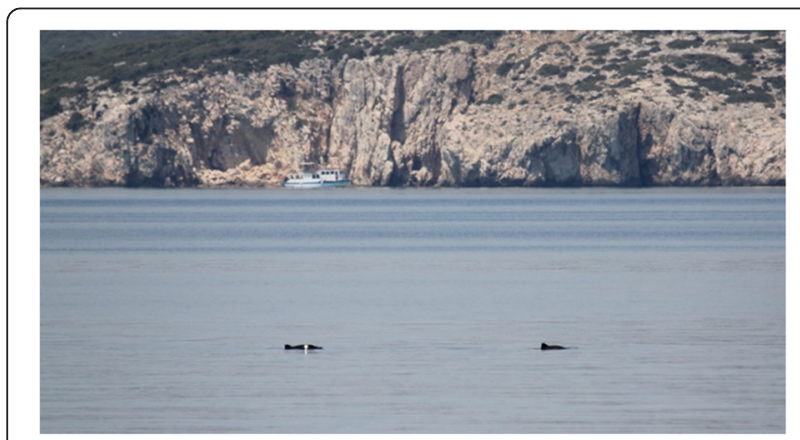

Fig. 4 A photograph of a harbour porpoise encounter with two individuals in Saros Bay, Thracian Sea (26/07/2013 10:34 UTC)
Tonay \& Dede 2013 and Pelagos Cetacean Research Institute, unpublished data) indicating that these animals may have been immunocompromised prior to stranding.

Strandings of harbour porpoises have been recorded in all months of the year with no obvious seasonal peak. Between 1997 and 2013, a maximum of five stranded harbour porpoises a year have been reported (in 2013), however there were 5 years (1998, 1999, 2001, 2002 and 2010) in which no harbour porpoise strandings were reported. Figure 6 displays all available data relating to harbour porpoise presence in the Aegean Sea collected over the last two decades including previously unpublished data from the Pelagos Cetacean Research Institute and the sightings and detections from this survey.

\section{Comparison of acoustic encounter rates}

The high resolution (coastal) survey of the Thracian Sea was found to have an acoustic encounter rate of 0.43 / $100 \mathrm{~km}(\mathrm{SE}=0.33)$ (using only click trains with seven or more clicks to allow comparison with previous surveys). This encounter rate is comparable to the Baltic Proper, an area known to have a very low density of porpoises $(0.1 / 100 \mathrm{~km})$, however it is markedly lower than the encounter rates in the Little Belt (Denmark), which is known to have a high harbour porpoise density (16.8/ $100 \mathrm{~km}$; Gillespie et al. 2005). It is also lower than the 


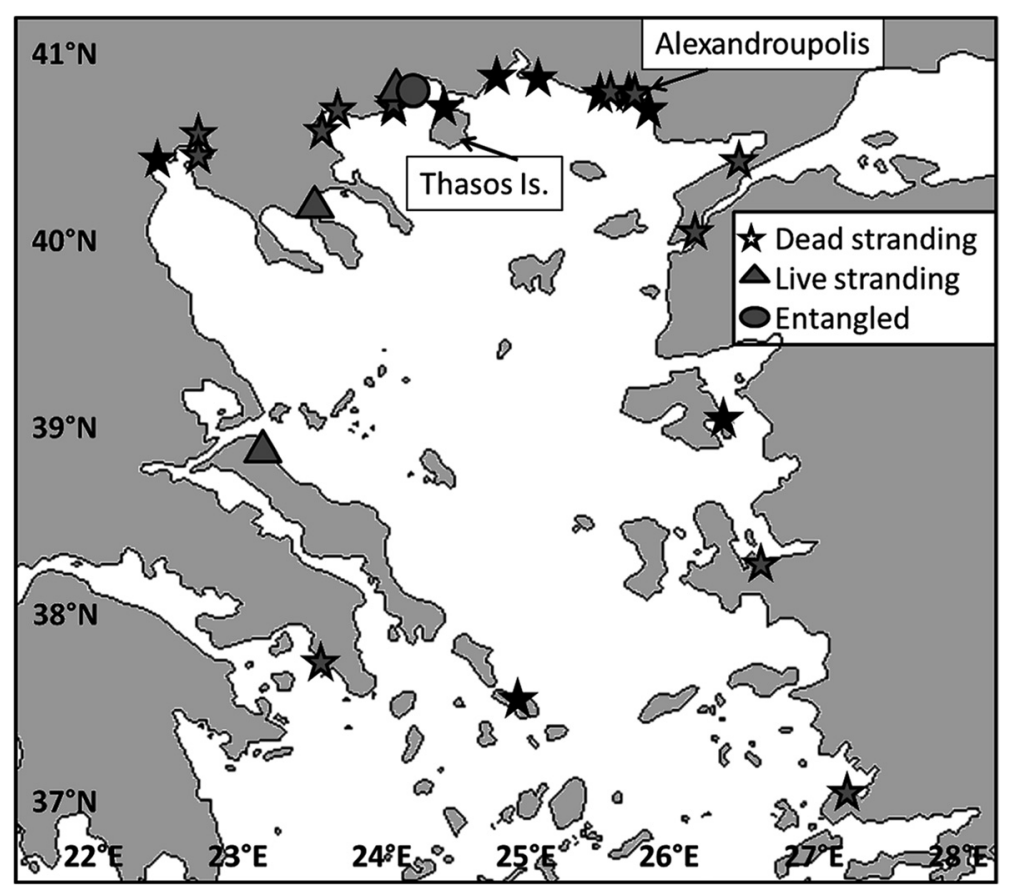

Fig. 5 Harbour porpoise strandings in the Aegean Sea and Çanakkale Strait $(n=29)$; of these, dead strandings $(n=25)$, live strandings $(n=3)$ and entangled $(n=1)$. Including previous published strandings (noted by grey stars, $n=19$ ) as well as 10 previously unpublished strandings from the Pelagos Cetacean Research Institute (marked as black stars)

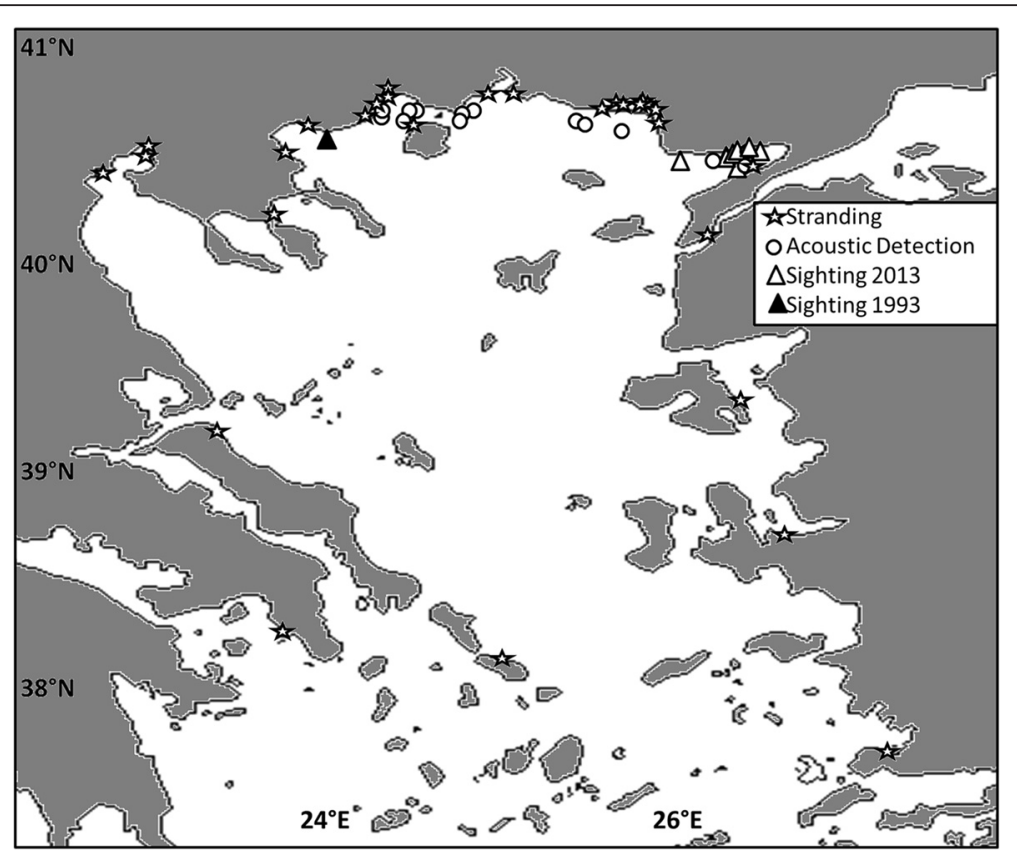

Fig. 6 All harbour porpoise sightings, strandings and acoustic detections recorded over the last two decades in the Aegean Sea and Çanakkale Strait. Strandings $(n=29)$, acoustic detections from this 2013 study $(n=16)$, sightings from this 2013 study $(n=9)$ and previous sightings $(n=1)$ 
waters between Dakhla and Cape Barbas off NW Africa (6/100 km; Boisseau et al. 2007).

\section{Discussion}

This study represents the first dedicated survey for harbour porpoises conducted in the Mediterranean Sea. It confirms the presence of free-swimming harbour porpoises in Greek and Turkish waters of the northern Aegean Sea in summer 2013. The inconspicuous nature of harbour porpoises severely reduces the probability of seeing individuals in sea conditions above sea state two (Teilmann 2003) and reduces significantly above sea state three (Palka 1996). Due to these challenges, harbour porpoises are not easy to observe in anything but perfect sea conditions. Although the mode sea state during this survey was two, during many parts of the survey the sea state exceeded three, thus compromising sighting conditions and highlighting the value of passive acoustic detection techniques in surveys for inconspicuous, vocallyactive species. It is worth noting that all harbour porpoise sightings in this study were made when the sea-state was between zero and one and porpoises were never visually detected in higher sea states, even in blocks where several acoustic detections were made.

There were a total of 21 distinct acoustic or visual detections of harbour porpoises throughout the survey (visual $n=5$, acoustic $n=12$ and combined $n=4$ ) grouped in three discrete blocks: north of the Greek Island of Thasos; southwest of Alexandroupolis; and Saros Bay, Turkey where the highest encounter rate (acoustic and/or visual) was recorded. Similar to porpoise populations in the Atlantic (Hammond et al. 2008) and Black Sea (Birkun \& Frantzis 2008), the harbour porpoises were all encountered in shallow $(<150 \mathrm{~m})$ coastal habitat (within $<6 \mathrm{~nm}$ of land). The sea-surface temperature in Saros Bay, where the highest density of porpoises occurred, was up to $25{ }^{\circ} \mathrm{C}$, above the previously postulated "limiting thermocline" for the species (Tolley \& Rosel 2006) and to the authors' knowledge, may be the warmest sea surface temperatures in which harbour porpoises have been observed. Although no previous systematic survey for harbour porpoises had been conducted in the Thracian Sea, parts of this area had previously been surveyed for cetaceans. During spring and summer visual surveys of the Turkish waters of the Aegean Sea between 2005 and 2008, including Saros Bay, no harbour porpoises were observed (Dede \& Öztürk 2007; Öztürk et al. 2009; Altuğ et al. 2011); possibly due to poor sea state or disturbance from the motor research vessel. Previous strandings data indicated the presence of porpoises in the Aegean Sea was largely confined to the northern Thracian Sea coast with several strandings northwest of Thasos Island and close to Alexandroupolis (Birkun \& Frantzis 2008). The results of this survey are consistent with the distribution of strandings in the region. However, this study highlights Saros Bay as an additional potentially significant area for porpoises, with the highest relative acoustic encounter rate in a location with just one previously reported stranding (Tonay et al. 2009; Tonay et al. 2012). This demonstrates the importance of using both strandings and systematic surveys to inform our understanding of harbour porpoise distribution. The recent increase in the number of strandings in the more southerly latitudes of the Aegean Sea suggest a possible increase in the range of harbour porpoise in this area; however the presence of high parasite loads in three of the six southerly strandings (Tonay \& Dede 2013 and Pelagos Cetacean Research Institute unpublished data) may indicate difficulties in survival for porpoises in these southerly latitudes. The multiple sightings, and the presence of a calf in one of the groups, indicate that porpoises in the northern Aegean may be breeding there. That a pregnant porpoise was found stranded north-west of Thasos Island further supports this hypothesis. With the Black Sea population of harbour porpoises estimated from genetic analysis to be just $10 \%$ of its former size (Fontaine et al. 2010), and considering the unknown status of harbour porpoises in the Mediterranean Sea, signs of a possible breeding group of porpoises in the Aegean Sea are highly significant. Considering that porpoises occur in the northern Aegean Sea in low relative abundances, occasionally with calves and exhibit an apparent preference for coastal waters, management measures towards their protection are warranted. The porpoises within the Black and Aegean Seas face many anthropogenic threats including pollution, climate change, fisheries bycatch and habitat degradation (Notarbartolo di Sciara 2002). As an example, a fisheries survey in the 1990s revealed 996 licensed fishing vessels with 964 set nets and longlines, 29 purse seines, two trawls, and one beach seine operating in Turkish waters of the northern Aegean Sea alone (Kara \& Gurbet 1999). Since this study was published the number of registered fishing vessels has increased, Ayaz et al. (2008) reported that there were about 250 fishermen using gillnets and trammel nets in Saros Bay. One of the animals listed as stranded in this study demonstrated evidence of entanglement in fishing gear (Fig. 5). As information on the levels of harbour porpoise bycatch in fisheries within the Mediterranean Sea is currently lacking, efforts are needed to quantify and reduce bycatch in all fisheries, especially in the Thracian Sea. Additionally, more information on the distribution of harbour porpoises in the Aegean Sea is required, especially seasonally and through the Turkish Straits System.

In small discrete porpoise populations, such as that in the northern Aegean Sea, monitoring trends in abundance is essential to maintaining their conservation status. The Baltic Sea and north west African coastal 
waters are both areas considered to have discrete harbour porpoise subpopulations (Huggenberger et al. 2002; Tolley \& Rosel 2006) with the Baltic Proper population being critically endangered due to its low density (Hammond et al. 2008). The results from this first dedicated northern Aegean Sea survey reveal acoustic encounter rates which are comparable to that of the Baltic Proper. Scientists studying small populations of phocoenids, such as harbour porpoises in the Baltic Sea and vaquita in the Gulf of California, have, following initial vessel and aerial surveys, established large arrays of autonomous acoustic recording devices to facilitate longer term monitoring of certain areas (Rojas-Bracho et al. 2010; Benke et al. 2014). Now that harbour porpoise presence has been confirmed in the Aegean Sea from this study, and certain areas noted as potentially significant, fixed acoustic devices have the potential to be used here to monitor presence and detect changes in abundance of porpoises more rapidly and over extended periods of time. As such it is recommended that relevant agencies, such as ACCOBAMS and the Turkish and Greek governments, consider these methods to monitor this small population in order to target further protection and assess the efficacy of conservation measures to reduce anthropogenic threats. Zones for marine protected area (MPA) designation have already been suggested in the high seas of the Aegean Sea (Öztürk 2009). In certain areas, such as the coastline off Alexandroupolis, and north of Thasos Island, the need for designation of MPAs has been noted; the information presented here supports the case for the creation of marine Natura 2000 sites with harbour porpoises as a qualifying interest (PCRI 2009). In recognition of the high biodiversity in Saros Bay, the Bay was declared an MPA in January 2011 and limitations have been set on the large-scale trawling, purse-seining and bivalve dredging fisheries in the area. This is a positive development in terms of conservation but, at present there are no limitations on gillnet fisheries, which have been described as "the single most important threat to porpoises" in other areas (Jefferson \& Curry 1994) and their prevalence in the region is of serious concern. In light of new evidence presented here on the presence and distribution of harbour porpoises in the northern Aegean Sea in both Greek and Turkish waters, a sharp focus on the protection of this small, coastal and possible breeding group is urgently required.

\footnotetext{
Abbreviations

ACCOBAMS, the agreement on the conservation of Cetaceans in the Black Sea, Mediterranean Sea, and contiguous Atlantic area; IUCN, International Union for Conservation of Nature; MPA, marine protected area; SD, standard deviation; SE, standard error; SOTW, song of the Whale (the survey research vessel).
}

\section{Acknowledgements}

This project was funded by the International Fund for Animal Welfare (IFAW) and Pelagos Cetacean Research Institute (PCRI) and planned and executed in collaboration with Dr. Alexandros Frantzis and the PCRI team. Additional field expertise and logistical support was provided by Dr. Bayram Öztürk of the Turkish Marine Research Foundation (TUDAV). Special thanks to Dr. Giuseppe Notarbartolo di Sciara and Dr. Tim Lewis for advice during the planning stages of the project and the ACCOBAMS Secretariat for continued encouragement. The team are grateful to the Greek and Turkish authorities for providing clearance for this survey and to the British Foreign and Commonwealth Office for their help facilitating the permits. Many thanks to Dr. Manos Koutrakis (Fisheries Research Institute of Kavala), Giannis Fakriadis (Management body of Evros Delta Natura 2000 area) and the personnel of the management body of Vistonida Natura 2000 area for sharing information regarding porpoise strandings and to Justin Matthews for looking over the statistical calculations in this paper. Thanks also to all those who participated in the Thracian Sea survey; Richard McLanaghan (MCR), Mat Jerram (MCR), Brian Morrison (MCR), Edd Hewett (MCR), Clare Gibson (MCR), Luke O'Connor $(\mathrm{MCR})$, Eleni Kytinou (PCRI), Myrto Tourgeli Provata (PCRI), Ekrem Hacioglu and Macit Ege Ercan (TUDAV).

\section{Funding}

Funding was received from the International Fund for Animal Welfare (IFAW) and the Pelagos Cetacean Research Institute (PCRI). The International Fund for Animal Welfare owned the research vessel Song of the Whale. Dr. Alexandros Frantzis from the Pelagos Cetacean Research Institute helped conceive the design of the study, provide historic datasets and read and approve the final manuscript.

\section{Authors' contributions}

ACC participated in the survey planning, leading the survey team, data analysis and drafting of the manuscript. AF, OB and $A M$ conceived of the study, and participated in its design and coordination. $O B, M R, C R, A O, A T$ and $A P$ all participated in the survey, $O B$ and MR supervised the data analysis and additionally $\mathrm{AO}, \mathrm{AF}$ and AT provided historic unpublished datasets to the manuscript. All authors read and approved the final manuscript.

\section{Competing interests}

The authors declare that they have no competing interests.

\section{Data sharing}

The data will not be shared publically through this forum. The raw data are audio files and databases which were then analysed further. If organisations, students or the public would like to use the data for further studies, please get in touch at MCRinfo@mr-team.org.

\section{Author details}

${ }^{1}$ Marine Conservation Research International, 94 High Street, Kelvedon, Essex CO5 9AA, UK. ${ }^{2}$ Pelagos Cetacean Research Institute, Terpsichoris 21, 16671 Vouliagmeni, Greece. ${ }^{3}$ Faculty of Fisheries, Istanbul University, Ordu. Cad. No:200 Laleli, 34480 Istanbul, Turkey. ${ }^{4}$ Turkish Marine Research Foundation (TUDAV), P.O. Box: 10 Beykoz, Istanbul, Turkey.

Received: 12 May 2016 Accepted: 3 June 2016

Published online: 12 July 2016

\section{References}

Abel O. Eine Stammtype der Delphiniden aus dem Miocän der Halbinsel Taman. Jahrbuch K K Geolog Reichsanstalt. 1905;55:375-92.

Altuğ G, Aktan Y, Oral M, Topaloğlu B, Dede A, Keskin Ç, İşinibilir M, Çardak M and Çiftçi PS. Biodiversity of the northern Aegean Sea and southern part of the Sea of Marmara, Turkey. Mar Biodivers Rec. 2011;4:e65.

Ayaz A, Işmen A, Altınağaç U, Özekinci U, Ayyıldız H. Technical features and structural differences of bottom gill and trammel nets in Saroz Bay (Turkey). J Fish Sci. 2008;2(3):499-505 (in Turkish with English abstract).

Bellido JJ, Castillo JJ, Farfán MA, Martín JJ, Mons JL, Real R. Ejemplar enfermo de Marsopa Phocoena phocoena (Linneaus, 1758) varado en las costas de Málaga. Galemys. 2006;18(1-2):37-9.

Benke H, Bräger S, Dähne M, Gallus A, Hansen S, Honnef CG, Jabbusch M, Koblitz JC, Krügel K, Liebschner A, Narberhaus I and Verfuß UK. Baltic Sea harbour porpoise populations: Status and conservation needs derived from recent survey results. Mar Ecol Prog Ser. 2014;495:275-90.

Birkun A.Jr. and Frantzis A. (2008) Phocoena phocoena ssp.relicta. In: IUCN 2012. IUCN Red List of Threatened Species. Version 2012.2. www.iucnredlist.org/ details/17030/0 (accessed 12 Sept 2013). 
Birkun A. Jr., Northridge S. P., Willsteed E. A., James F. A., Kilgour C., Lander M. and Fitzgerald G. D. (2014) Studies for Carrying Out the Common Fisheries Policy: Adverse Fisheries Impacts on Cetacean Populations in the Black Sea. Final report to the European Commission, Brussels, 347p.

Boisseau O, Matthews J, Gillespie D, Lacey C, Moscrop A, El Ouamari N. A visual and acoustic survey for harbour porpoises off North-West Africa: further evidence of a discrete population. Afr J Mar Sci. 2007;29:403-10.

Buckland ST, Anderson DR, Burnham KP, Laake JL, Borchers DL, Thomas L. Introduction to Distance Sampling. Oxford: University Press; 2001

Data Mapper (2012) Schlitzer, R., Ocean Data View, http://odv.awi.de, 2012.

Danyer E, Tonay AM, Aytemiz I, Dede A, Yildirim F, Gurel A. First report of infestation by a parasitic copepod (Pennella balaenopterae) in a harbour porpoise (Phocoena phocoena) from the Aegean Sea: a case report. Vet Med. 2014;59(8):403-7

Dede A. and Öztürk B. (2007) Cetacean observations in the Marmara and Aegean Sea in spring season 2005. Report from the Commission of International Scientific Exploration of the Mediterranean Sea 38: 455

Fontaine MC, Baird SJE, Piry S, Ray N, Tolley KA, Duke S, Birkun Jr A, Ferreira M, Jauniaux T, Llavona A, Ozturk B, Ozturk AA, Ridoux V, Rogan E, Sequeira M, Siebert U, Vikingsson GA, Bouquegneau J-M and Michaux JR. Rise of oceanographic barriers in continuous populations of a Cetacean: the genetic structure of harbour porpoises in old world waters. BMC Biol. 2007;5:30.

Fontaine MC, Tolley KA, Michaux JR, Birkun Jr A, Ferreira M, Jauniaux T, Llavona A, Öztürk B, Öztürk AA, Ridoux V, Rogan E, Sequeria M, Bouquegneau J-M and Baird SJE. Genetic and historic evidence for climate-driven population fragmentation in a top Cetacean predator: the harbour porpoises in European Waters. Proc R Soc Biol. 2010;227:2829-37.

Fontaine MC, Alodie Snirc A, Frantzis A, Koutrakis E, Birkun Jr A, Ozturk B, Ozturk AA, and Austerlitz F. A history of expansion and anthropogenic collapse in a top marine predator of the Black Sea estimated from genetic data. Proc Natl Acad Sci U S A. 2012;109(38):E2569-76.

Frantzis A. Cetaceans in Greece: Present status of knowledge. Technical Report Athens: Initiative for the Conservation of Cetaceans in Greece; 2009. p. 94.

Frantzis A, Gordon J, Hassidis G, Kommenou A. The enigma of harbour porpoise presence in the Mediterranean Sea. Mar Mamm Sci. 2001;17(4):937-44.

Frantzis A, Alexiadou P, Paximadis G, Politi E, Gannier A, Corsini-Foka M. Current knowledge of the cetacean fauna of the Greek Seas. J Cetacean Res Manag. 2003:5(3):219-32.

Galatius A, Gol'din PE. Geographic variation of skeletal ontogeny and skull shape in the harbour porpoise (Phocoena phocoena). Can J Zool. 2011;89(9):869-79.

Gaskin DE. The harbour porpoise Phocoena phocoena (L.): Regional populations, status, and information on direct and indirect catches. Rep Int Whaling Comm. 1984;34:569-86

Gillespie D, Leaper R, Gordon J, MacLeod K. An Integrated Data Collection System for Line Transect Surveys. J Cetacean Res Manag. 2010;11:217-27.

Gillespie D, Berggren P, Brown S, Kuklik I, Lacey C, Lewis T, Matthews J, McLanaghan R, Moscrop A, and Tregenza N. Relative abundance of harbour porpoises (Phocoena phocoena) from acoustic and visual surveys of the Baltic Sea and adjacent waters during 2001 and 2002. J Cetacean Res Manag. 2005;7(1):51-7.

Gillespie D, Mellinger DK, Gordon J, McLaren D, Redmond P, McHugh R, Trinder P, Deng X-Y and Thode A. PAMGUARD: Semiautomated, open source software for real-time acoustic detection and localisation of cetaceans. J Acoust Soc Am. 2009;125(4):2547.

Güçlüsoy $\mathrm{H}$. The first confirmed report of the harbour porpoise (Phocoena phocoena) in the Turkish Aegean Sea. Mar Biodivers Rec. 2007;1:e94.

Hammond PS, Bearzi G, Bjørge A, Forney K, Karczmarski L, Kasuya T, Perrin WF, Scott MD, Wang JY, Wells RS and Wilson B. (2008) Phocoena phocoena (Baltic Sea subpopulation). In: IUCN 2013. IUCN Red List of Threatened Species. Version 2013.2. <www.iucnredlist.org> Downloaded on 25 March 2014

Hammond PS, Macleod K, Berggren P, Borchers DL, Burt L, Cañadas A, Desportes G, Donovan GP, Gilles A, Gillespie D, Gordon J, Hiby L, Kuklik I, Leaper R, Lehnert K, Leopold M, Lovell P, Øien N, Paxton CGM, Ridoux V, Rogan E, Samarra F, Scheidat M, Sequiera M, Siebert U, Skov H, Swift R, Tasker ML, Teilmann J, Van Canneyt $\mathrm{O}$ and Vázquez JA. Cetacean abundance and distribution in European Atlantic shelf waters to inform conservation and management. Biol Conserv. 2013;164:107-22.

Huggenberger S, Benke H, Kinze CC. Geographical variation in harbour porpoise (Phocoena phocoena) skulls: support for a separate non-migratory population in the Baltic proper. Ophelia. 2002;56(1):1-12.

Jefferson TA, Curry BE. A global review of porpoise (Cetacea: Phocoenidae) mortality in gillnets. Biol Conserv. 1994;67(2):167-83.
Kara OF, Gurbet R. Investigation on industrial fishery of the Aegean Sea. Bodrum: The Republic of Turkey, Ministry of Agriculture and Rural Affairs, No: 5; 1999. p. 135. In Turkish.

Linnaeus, C. (1758). Systema naturae per regna tria naturae, secundum classes, ordinus, genera, species, cum characteribus, differentiis, synonymis, locis. Tomus I. Editio decima, reformata. Impensis Direct. Laurentii Salvii, Holmiae. 824.

Lykousis V, Chronis G, Tselepidis A, Price NB, Theocharis A, Sikou-Frangou I, Van Wambeke F, Danovaro R, Stavrakaki S, Duineveld G, Georgopoulos D, Ignatiades L, Souvermezoglou A and Voutsinou-Taliadouri F. Major outputs of the recent multidisciplinary biogeochemical researches undertaken in the Aegean Sea. J Mar Syst. 2002;34:313-34.

Notarbartolo di Sciara G. (2002) Introduction. In: G. Notarbartolo di Sciara (Ed.), Cetaceans of the Mediterranean and Black Seas: state of knowledge and conservation strategies. A report to the ACCOBAMS Secretariat, Monaco, February 2002. Section 2, 3 p.

Notarbartolo di Sciara G, Birkun Jr A. Conserving Whales, Dolphins and Porpoises in the Mediterranean and Black Seas, ACCOBAMS Status Report 2010. Monaco: ACCOBAMS; 2010. p. 212

Otani S, Naito Y, Kato A, Kawamura A. Diving behaviour and swimming speed of a free-ranging harbour porpoise, Phocoena phocoena. Mar Mamm Sci. 2006;16(4):811-4.

Öztürk AA. In: Evans PGH, editor. A brief review of chemical pollution in Black Sea cetaceans, ECS Special Publication Series. Cadiz: Proceedings of the ECS/ ASCOBANS/ACCOBAMS Joint workshop on Chemical pollution and marine mammals; 2013. p. 85-9.

Öztürk B. (2009) Marine protected area in the high seas of the Aegean and Eastern Mediterranean Seas, some proposals. Journal of the Black Seal Mediterranean Environment 15:69-82.

Öztürk B, Dede A, Tonay A, Öztürk AA. (2009) Cetacean sightings in the Aegean Sea in summer 2007 and 2008. Poster presented at the 23rd Annual Conference of the European Cetacean Society $2^{\text {nd }}-4^{\text {th }}$ March 2009 , Istanbul Turkey. 114p.

Palka D. Effects of Beaufort Sea State on the Sightability of Harbour porpoises in the Gulf of Maine. Rep Int Whaling Comm. 1996;46:575-82.

PCRI (2009) Pelagos Cetacean Research Institute Extension of old and creation of new Natura 2000 areas aiming at better conservation of cetaceans of the Greek Seas. Workshop for the identification of new marine Natura 2000 areas, 13 December 2009, Ministry of Environment Energy and Climate Change, Powerpoint presentation, slide 13. Available at: www.ypeka.gr/ LinkClick.aspx?fileticket=h5gje3HnslE\%3d\&tabid=710\&language $=\mathrm{el}-\mathrm{GR}$

Read A. Harbour porpoise - Phocoena phocoena (Linnaeus, 1758). In: Ridgway S, Harrison S, editors. Handbook of marine mammals: the second book of dolphins and porpoises, vol. 6. San Diego: Academic; 1999. p. 323-56.

Rojas-Bracho L., Jaramillo-Legorreta A., Cardenas G., Nieto E., Ladrón de Guevara P., Taylor B., Barlow J., Gerrodette T., Henry A., Tregenza N., Swift R., and Akamatsu, T. (2010) Assessing trends in abundance for vaquita using acoustic monitoring: Within refuge plan and outside refuge research needs. NOAA Technical Memorandum, National Marine Fisheries Service, Southwest Fisheries Science Center 459. 39 pp.

Rosel PE, Dizon AE, Haygood MG. Variability of the mitochondrial control region in populations of the harbour porpoise, Phocoena phocoena, on interoceanic and regional scales. Can J Fish Aquat Sci. 1995;52:1210-9.

Rosel P.E, Frantzis A, Lockyer C, and Komnenou A. Source of Aegean Sea harbour porpoises. Mar Ecol Prog Ser. 2003;247:257-61.

Ryan C., Cucknell A-C., Romagosa M., Boisseau O., Moscrop A., Frantzis A. and McLanaghan R. (2014) A visual and acoustic survey for marine mammals in the Eastern Mediterranean Sea during summer 2013. Final report for a cetacean acoustic and visual survey of the Aegean and eastern Mediterranean Seas, July-September 2013, submitted to IFAW, April 2014 http://tinyurl.com/l6bnhz2.

Teilmann J. Influence of sea state on density estimates of harbour porpoises (Phocoena phocoena). J Cetacean Res Manag. 2003;5(1):85-92.

Thomas L, Buckland ST, Rexstad EA, Laake JL, Strindberg S, Hedley SL, Bishop JRB, Marques TA and Burnham KP. Distance software: design and analysis of distance sampling surveys for estimating population size. J Appl Ecol. 2010;47:5-14.

Tolley K, Rosel PE. Population structure and historical demography of eastern North Atlantic harbour porpoises inferred through mtDNA sequences. Mar Ecol Prog Ser. 2006;327:297-308.

Tonay A.M., Dede A., Öztürk A. and Öztürk B. (2009) Cetacean strandings in the Turkish Straits System (TSS) and the Northern Aegean Sea coast of Turkey 
during 1999-2008. Poster presented at the 23rd Annual Conference of the European Cetacean Society, 2nd-4th March, 2009 Istanbul, Turkey

Tonay A.M., Yazııı Ö., Dede A., Bilgin S., Maracı Ö., Öztürk A.A. and Bilgin R. (2014) Variability of the mitochondrial control region in the populations of the Black Sea harbour porpoise (Phocoena phocoena relicta) in the Turkish Seas. Poster presented at 28th Annual Conference of the European Cetacean Society, 5th-9th April 2014 Liege, Belgium, 235p

Tonay AM, Dede A, Maracı Ö, Bilgin R. A preliminary genetic study on the harbour porpoise (Phocoena phocoena) in the Turkish Seas. J Black Sea/ Mediterr Environ. 2012;18(1):83-9.

Tonay A.M., Yazııı Ö., Dede A., Bilgin S., Maracı Ö., Öztürk A.A. and Bilgin R. (2014) Variability of the mitochondrial control region in the populations of the Black Sea harbour porpoise (Phocoena phocoena relicta) in the Turkish Seas. Poster presented at 28th Annual Conference of the European Cetacean Society, $5^{\text {th }}-9^{\text {th }}$ April 2014 Liege, Belgium, 235p.

Viaud-Martínez KA, Vergara MM, Gol'din PE, Ridoux V, Öztürk AA, Öztürk B, Rosel PE, Frantzis A, Komnenou A, and Bohonak AJ. Morphological and genetic differentiation of the Black Sea harbour porpoise, Phocoena phocoena. Mar Ecol Prog Ser. 2007;338:281-94.

Villadsgaard A, Wahlberg M, Tougaard J. Echolocation signals of wild harbour porpoises, Phocoena phocoena. J Exp Biol. 2006;210:56-64.

\section{Submit your next manuscript to BioMed Central} and we will help you at every step:

- We accept pre-submission inquiries

- Our selector tool helps you to find the most relevant journal

- We provide round the clock customer support

- Convenient online submission

- Thorough peer review

- Inclusion in PubMed and all major indexing services

- Maximum visibility for your research

Submit your manuscript at www.biomedcentral.com/submit

) Biomed Central 